\title{
Estimative of royalties: appropriation of gains provided by innovations associated
}

\section{with plant breeding}

\author{
Estimativa de royalties: apropriação dlos ganhos proporcionados pelas inovações associadlas ao \\ melhoramento de plantas
}

Regalías estimadas: apropiación de ganancias generadas por innovaciones asociadas con el mejoramiento de plantas

Received: 10/06/2021 | Reviewed: 10/14/2021 | Accept: 10/18/2021| Published: 10/20/2021

Eduardo José de Souza Silva

ORCID: https://orcid.org/0000-0003-3429-6236 Universidade Federal de Sergipe, Brasil

E-mail: eduardojcufs@gmail.com

Crislaine Costa Calazans

ORCID: https://orcid.org/0000-0002-6100-0608 Universidade Federal de Sergipe, Brasil E-mail: cris.calazans@yahoo.com.br

Valdinete Vieira Nunes

ORCID: https://orcid.org/0000-0002-0272-0971 Universidade Federal de Sergipe, Brasil E-mail: nunes.vval@gmail.com

Renata Silva-Mann

ORCID: https://orcid.org/0000-0001-5993-3161 Universidade Federal de Sergipe, Brasil E-mail: renatamann@academico.ufs.br

\begin{abstract}
Genetic breeding is based on the inheritance of quantitative traits, which provides the basis for developing methods that can be used to increase the rate of genetic improvement, known as genetic gain. Through selection, new varieties of plants can be obtained, which can be protected. Thus, this research investigates the mechanisms for estimating royalties in protected cultivars and the importance of genetic gains in such estimations. A systematic review was carried out based on articles published in 10 years, from 2009 to 2019, in the scientific bases Scopus (71) and Web of Science (73). The main crop, take as an example, was sugar cane. A survey of documents was carried out containing the Boolean terms and operators: "(genetic * and gain) and (sugarcane or cane)" in the title and/or abstract. One hundred forty-four articles were searched. After processing the data and removing duplicate documents, 107 scientific articles remained. With an average publication of 6.38 publications per year. Average of 14.6 citations per document. There were 463 authors and 456 co-authors, with nine documents having single authorship and an average of 4.33 authors per article. After the refinement process, a study sample of 25 articles was obtained. The analyzed journals provided information about the estimates, applied model, and study variables, being of great importance in constructing a linear regression model of royalty valuation linked to intellectual property rights related to the breeder of plant breeding.
\end{abstract}

Keywords: Genetic improvement; Productivity; Intellectual property.

\section{Resumo}

O melhoramento genético é baseado na herança de características quantitativas, que fornece a base para o desenvolvimento de métodos que podem ser usados para aumentar a taxa de aprimoramento genético, conhecido como ganho genético. Por meio da seleção no melhoramento pode-se obter novas variedades de plantas, as quais podem ser protegidas. Dessa forma, essa pesquisa objetiva investigar os mecanismos de estimativa de royalties em cultivares protegidas com base em ganhos genéticos. Foi realizada uma revisão sistemática a partir de artigos publicados no período de 10 anos, de 2009 até 2019, nas bases científicas Scopus (71) e Web of Science (73). Realizou-se um levantamento de documentos contendo os termos e operadores booleanos com foco na cultura da cana-de-açúcar: "(genetic* and gain) and (sugarcane or cane)" no título e/ou resumo. Foram prospectados 144 artigos, após o tratamento dos dados e remoção de documentos duplicados restaram 107 artigos científicos. Com uma publicação média de 6,38 publicações por ano. Média de 14,6 citações por documento. Um total 463 autores e 456 coautores, sendo nove documentos de autoria única e em média de 4,33 autores por artigo. Após o processo de refinamento, obteve-se uma amostra de estudo de 25 artigos. Os periódicos analisados fornecem informações sobre as 
estimativas, modelo aplicado e as variáveis de estudo dados de grande importância para construção de um modelo de regressão linear múltiplo de valoração de royalties vinculado aos direitos de propriedade intelectual relativos ao obtentor de plantas.

Palavras-chave: Melhoramento genético; Produtividade; Propriedade intelectual.

\begin{abstract}
Resumen
La mejora genética se basa en la herencia de rasgos cuantitativos, lo que proporciona la base para el desarrollo de métodos que pueden utilizarse para aumentar la tasa de mejora genética, conocida como ganancia genética. Mediante la selección en el mejoramiento, se pueden obtener nuevas variedades de plantas, que se pueden proteger. Por lo tanto, esta investigación tiene como objetivo investigar los mecanismos para estimar las regalías en cultivares protegidos en función de las ganancias genéticas. Se realizó una revisión sistemática a partir de artículos publicados en el período de .10 años, de 2009 a 2019, en las bases científicas Scopus (71) y Web of Science (73). Se realizó un relevamiento de documentos que contenían los términos y operadores booleanos: "(genético * y ganancia) y (caña de azúcar o caña)" en el título y / o resumen. Se buscaron 144 artículos, luego de procesar los datos y remover documentos duplicados, quedaron 107 artículos científicos. Con una publicación media de 6,38 publicaciones al año. Promedio de 14,6 citas por documento. Un total de 463 autores y 456 coautores, con nueve documentos de una sola autoría y una media de 4,33 autores por artículo. Luego del proceso de refinamiento, se obtuvo una muestra de estudio de 25 artículos. Las revistas analizadas proporcionaron información sobre las estimaciones, modelo aplicado y variables de estudio, siendo de gran importancia en la construcción de un modelo de regresión lineal de valoración de regalías vinculado a derechos de propiedad intelectual relacionados con el obtentor de fitomejoramiento.
\end{abstract}

Palabras clave: Mejoramiento genético; Productividad; Propiedad intelectual.

\title{
1. Introduction
}

The 20th century was the period of the first plant breeding programs emerged and began to gain incentives and intellectual protection. One of the main factors was appropriating the gains provided by the innovations associated with cultivars. In most situations, this guarantee is a necessary condition to enable the investments required for conducting research, without which it would not be possible to achieve the innovations that allowed significant gains in agricultural productivity (Bruch \& Pinto Vieira, 2016). For seeds, which were and continue to be an essential input, public research institutions organized in international research and development (R\&D) networks had particular importance, especially in the context of the so-called Green Revolution. The genetic breeding of plants from the last decade changed the productive configuration, mainly in the productive chains of crops (Juk \& Fuck, 2020).

In technological innovations, one of the significant challenges is the valuation of the products obtained. This valuation is feasible and relatively easy for physical products, efficiently designed, and visible production costs. However, when considering new varieties of plants, it is not easy to think about this valuation in detail, and what is done is to consider production to estimate royalty rates. Thus, given the lack of detail in these royalty charges, gaps are opened for further research on the subject to better monitor production gains and tax them to return investments in obtaining new plant varieties (E. J. de S. Silva et al., 2021). For technological innovations of products that require intellectual protection, the World Intellectual Property Organization (WIPO), internationally, currently comprising 187 Members, aims to promote the protection of international intellectual property and thus act as essential allies of economic and social development. The increased participation of the private sector in plant breeding, initially in the development of varieties, boosted the creation of Intellectual Property Rights (IPR) for plant varieties that would encourage innovation and private investment (Juk \& Fuck, 2020). The protection of new varieties is of paramount importance given the high value of added technology that seeds have, intellectual property rights, and the aim of recognizing the moral rights of breeders.

In the world context, once a plant breeder has developed a new variety, he can protect innovation with a patent or plant breeder's right. These rights were established by the International Union for the Protection of New Varieties of Plants (UPOV) which involve rights similar to those guaranteed by a patent, with two notable exceptions: the patent does not allow private seed research for commercial and seed saving purposes (Hervouet \& Langinier, 2018). The consecutive cultivation and 
the high susceptibility to diseases led countries to produce the most diverse crops to initiate plant breeding programs. The genetic breeding programs for production primarily aim to select genotypes with high production per area due to agronomical, yield, and phytosanitary traits (Bezerra et al., 2018).

In Brazil, the introduction of plant varieties of some crops was done exclusively through importation until genetic breeding programs emerged, which were efficient in obtaining cultivars for several crops with economic importance, for example, corn, soybeans, cotton, and sugar cane. Among the agricultural species, sugarcane is an economic asset with strategic importance for Brazil, helping the country remain among the largest producers and exporters of agricultural products globally. Currently, Brazil is the world's second-largest sugarcane producer. According to FAO, prospects are that it will once again become the leading producer, totaling $39 \%$ of the world's sugarcane production for 2029. Furthermore, it will be responsible for $18 \%$ of global sugar production and $90 \%$ of global ethanol production (OECD/FAO, 2020). Another reason why sugarcane stands out is due to its importance for the country's energy matrix, for the production of ethanol, specifically in recent years with the creation of the Federal Government program, RenovaBio, whose objective is to expand production biofuels in Brazil, based on predictability, environmental, economic and social sustainability, and compatible with market growth (MINISTÉRIO DE MINAS E ENERGIA, 2021). Due to its economic potential, sugarcane breeding programs are essential (Morini et al., 2017). Breeding programs are intended to develop more productive cultivars. Approximately one-third of the planted and cultivated area in the country is occupied by sugarcane cultivars developed in genetic breeding programs in three institutions in Brazil: the Inter-University Network for the Development of the Sugar-Energy Sector (RIDESA); the Sugarcane Center, from the Agronomic Institute of Campinas (IAC); and the Sugarcane Technology Center (CTC).

In the specific case of sugarcane, it is established that in order to multiply vegetative material, even for their use, the farmers must undertake - will obtain the authorization of the holder of the right to the cultivar (Brasil, 1997), which can be justified by the ease of propagation of the species, which occurs by vegetative propagation, conventionally from stem segments (EMBRAPA, 2021). In the literature, there are no parameters explicitly defined to establish the value of royalties to be charged for the use of cultivars. Such parameters are important to guarantee that creative companies' investment in $R \& D$ is recovered and also so that they can enjoy the financial results resulting from innovation. In this sense, some appropriation strategies are adopted by the companies: monitoring carried out by the company (from sowing to harvest) in order to control illegal practices; higher launch price as farmers save seeds for later years; rapid releases of new varieties so that genetics become obsolete, which convinces farmers to purchase new propagules every year; the combination of sui generis protection with the patenting of some biotechnological characteristic, which would result in an overcharge exerted by the patented trait if the farmer saves the seed; finally the use of the trademark for which royalties could be charged concerning cultivars that fall into the public domain (Endres \& Goldsmith, 2007; Goldsmith et al., 2006; Sá, 2018).

For technological innovations that result in new cultivars, the legal protection by sui generis right of intellectual property is subject to the confluence of five attributes: novelty, proper name, distinguishability, homogeneity, and stability (BRASIL, 1997). Further, for the production, processing, and marketing of its seeds and seedlings in the country, it must be registered with the National Registry of Cultivars (RNC). Therefore, the cultivar will be submitted to the Cultivation Value and Use (VCU) tests, in which agronomic traits and their combinations with the properties of use in agricultural, industrial, commercial, and consumption (Brasil, 2003). During the VCU tests, it is possible to estimate the genetic gains since experiments are carried out per hectare in which the varieties are released in different years and evaluated in field experiments. The characteristics are evaluated in at least two different crop years and in the year the variety is released, and the genetic gain estimation allows plant breeding organizations to measure and adjust the periodic range of genetic gain. It also quantifies the efficiency of new technologies incorporated into a program (Masuka et al., 2017).

Periodic evaluation of cultivar performance is essential to determine relative genetic gains over time, using obsolete 
and new cultivars and indicating a program's efficiency. The genetic gains of cultivars refer to the increase in yield and quality derived from the continuous release of cultivars over time, and it is the continuous genetic breeding that benefits producers (Zhou \& Gwata, 2016). Genetic breeding is a great tool to ensure sustainability, reduce costs, crop efficiency, and increase productivity. This development is related to the property of the technology inserted in the plant. Therefore, it is essential to evaluate the genetic gain associated with the royalty estimate. In order to access knowledge about genetic gain and associate it with return values in economic gains for research and profit, reflected in royalty values, it is necessary to access state of the art related to the subject. For this, a systematic review can be used as a methodological tool. Through this tool, it is possible to access information that responds to a well-defined research question and is characterized by being methodologically transparent and replicable. It allows exploring a specific topic efficiently by presenting impartial aspects. Thus, it presents itself as an indispensable tool. It aims to reduce bias through explicit methods to conduct a comprehensive literature search and critically evaluate individual studies (Donato \& Donato, 2019).

This type of investigation summarizes evidence related to a specific intervention strategy by applying explicit and systematized search methods, critical analysis, and synthesis of selected information (Medeiros et al., 2015). Thus, this research aims to investigate the mechanisms for estimating royalties in cultivars and verifying the possibility of using explicitly weighted genetic gain values as a basis.

\section{Methodology}

In this study, a systematic review of genetic gain was carried out. The study is descriptive, exploratory, qualitative, and quantitative. Initially, data referring to the scientific production on the subject have prospected. A review was performed based on articles published over ten years, from 2009 to 2019, in Scopus's scientific databases (http://www.scopus.com) and Web of Science (http://www.webofknowledge. with). Data were obtained and analyzed with the help of $\mathrm{R}$ software version 4.0.2 (R Core Team, 2020) and RStudio version 1.1.463 (RStudio Team, 2016). Bibliometric analysis, statistics, and construction of the $\mathrm{R}$ software were used for bibliographic coupling, co-citation, scientific collaboration analysis, keyword analysis, and the Bibliometrix package of the R software (Aria \& Cuccurullo, 2017) it is interfaced with the Biblioshny browser (http://www.bibliometrix.org). The flowchart for scientific mapping is shown in Figure 1. 
Figure 1. Flowchart of scientific mapping of genetic gain in sugarcane-based on PRISMA (Preferred Reporting Items for Systematic Reviews and Meta-Analyses).

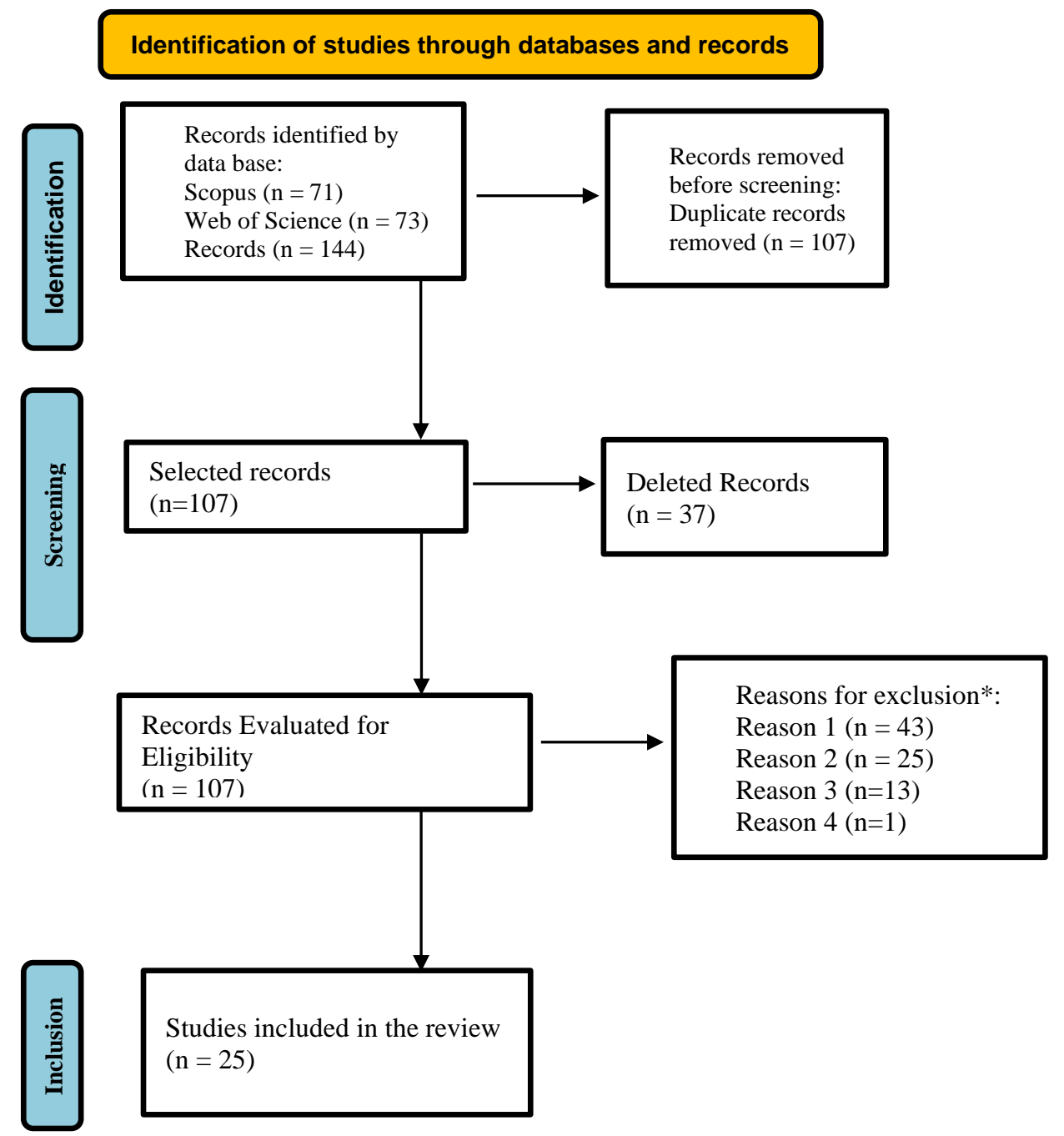

* Excluded records: Reason 1 - Articles not relevant to the topic without mathematical equations; Reason 2 - Articles not relevant to the topic after reading the abstracts; Reason 3 - Articles not relevant to the topic with mathematical expressions; Reason 4 - Articles not available on the web.

Source: Adapted (Page et al., 2021).

Figure 1 shows the PRISMA for systematic review based on pre-defined eligibility criteria and conducted according to a pre-defined methodological approach. The articles were screened by reading the title, abstract, and keywords with a confirmation step by examining the complete manuscript text form regarding the scientific production. The survey was conducted in March 2021 with the following Boolean terms and operators: "(genetic* and gain) and (sugarcane or cane)," which were prospected in the title and/or abstract of scientific articles. The data generated from the scientific articles obtained from the two databases were imported and incorporated into a database in BibTex format, the duplicates were removed, and a single data set was produced to carry out the analysis. The multi-platform geographic information system QGIS version 3.4 (QGIS.org, 2021) was used to obtain the geographic distribution of countries with sugarcane breeding centers that are part of the International Union for the Protection of New Varieties of Plants (UPOV).

\section{Results and Discussion}

One hundred forty-four documents indexed in the Scopus (71) and Web of Science (73) databases were examined. 
After processing the data and removing duplicate documents (37), 107 scientific articles remained. With an average publication of 6.38 publications per year. Average of 14.6 citations per document. There were 463 authors and 456 co-authors, with nine documents of single authorship and an average of 4.33 authors per article. The leading journals were Sugar Tech, International Sugar Journal, Genetics, Molecular Research, Rural Science, South African Journal of Plant and Soil, Crop Science, Agronomy Journal, Bioscience Journal. These Journals stand out with the highest impact factors (H- index) (Figure 2). As for the number of citations, the journals Sugar Tech (87), Ciência Rural (27), South African Journal of Plant and Soil (15), Genetics and Molecular Research (12), and Agronomy Journal (12) obtained the highest indexes.

Figure 2. Prominent journals regarding the number of articles published and the H-index.

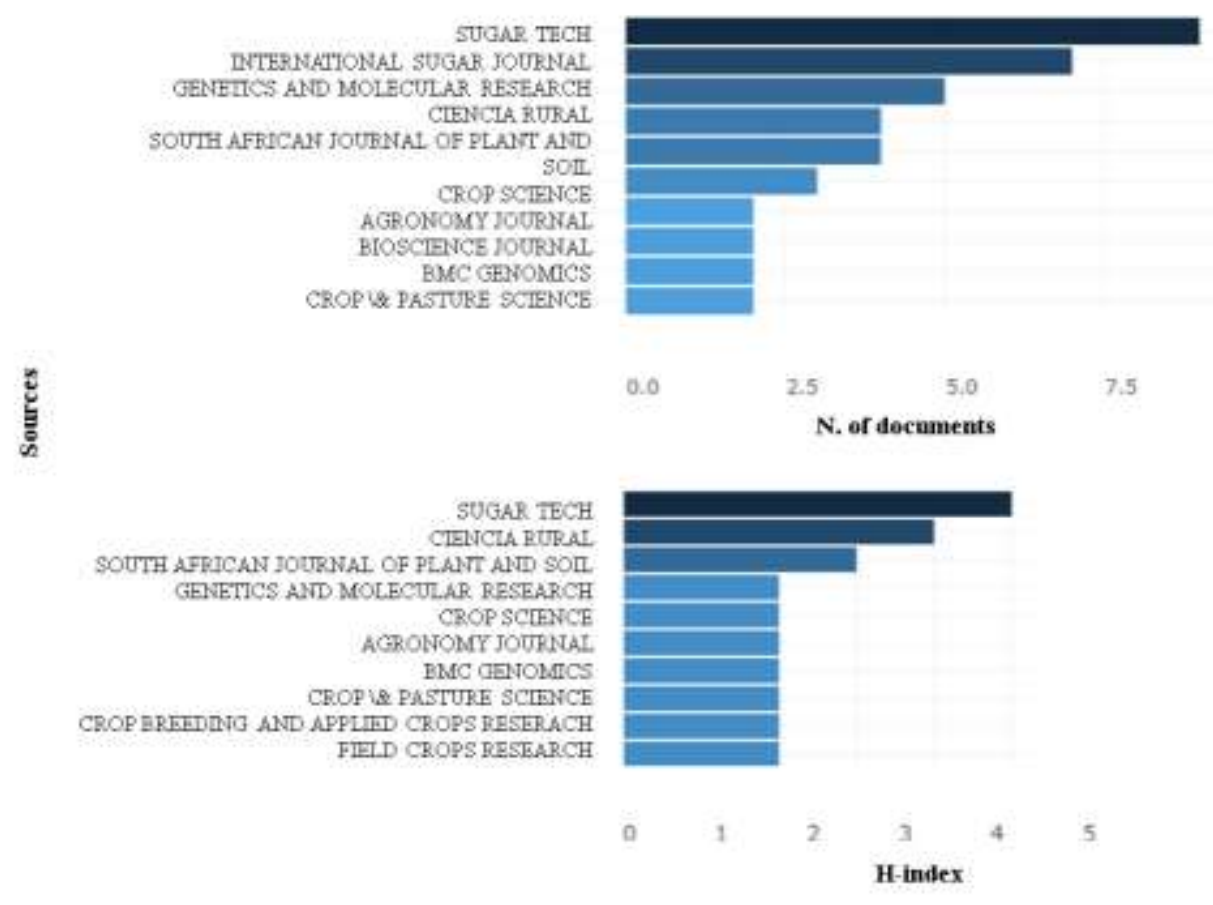

Source: Authors (2021).

Scientific journals are a vehicle for disseminating scientific production in a specific area of knowledge, and it is these areas organize and structure themselves to create, maintain, disseminate and preserve their information. In the scientific journal, knowledge can be disseminated in a more up-to-date and reliable way due to the periodicity and rigorous processes of peer review (R. S. Rodrigues \& Fachin, 2010). Scientific production indicators are usually used to assess the academic community. As a quality parameter, bibliographic databases select the most influential journals, which gives them a significant role in the evaluation process. Meta-analysis is a technique of crossing evidence (terms, variables, names, keywords, arguments, and others) that provides a rigorous association of previous studies on a specific theme, allowing the assessment of the research's global effect. This technique became helpful in developing knowledge about organizational sciences, producing essential contributions for future research agendas. The application of this technique makes it possible to systematically synthesize existing empirical results according to an evidence-based research approach. Thus, the meta-analysis provides directions and effects between the studied variables, allowing researchers to assess the heterogeneity of primary studies. Therefore, it integrates several primary studies, producing more comprehensive statistical control and, at the same time, avoiding the influence and potential statistical inadequacies of isolated studies (R. S. Pereira et al., 2019). 
Bradford's law allows us to estimate the degree of relevance of journals in a given area of knowledge, which journals produce the most significant number of articles on a given subject. They form a core of higher quality journals or relevance to a particular theme (Sembay et al., 2020). Thus, the formation of the group of central journals and respective ranks listed below were verified: Sugar Tech (9), Genetics and Molecular Research (5), Ciência Rural (4), South African Journal of Plant and Soil (4), and International Sugar Journal (7). The main terms found in the keywords were: Sugarcane (55.55\%), Weight Gain (16.66\%), Genetic (16.66\%), Diversity (13.88\%), Saccharum spp (13.88\%). The following journals stand out in annual publications: Genetics and Molecular Research, International Sugar Journal, and Sugar Tech (Figure 3).

Figure 3. Annual evolution of publications on genetic gain in sugarcane from 2009 to 2019.

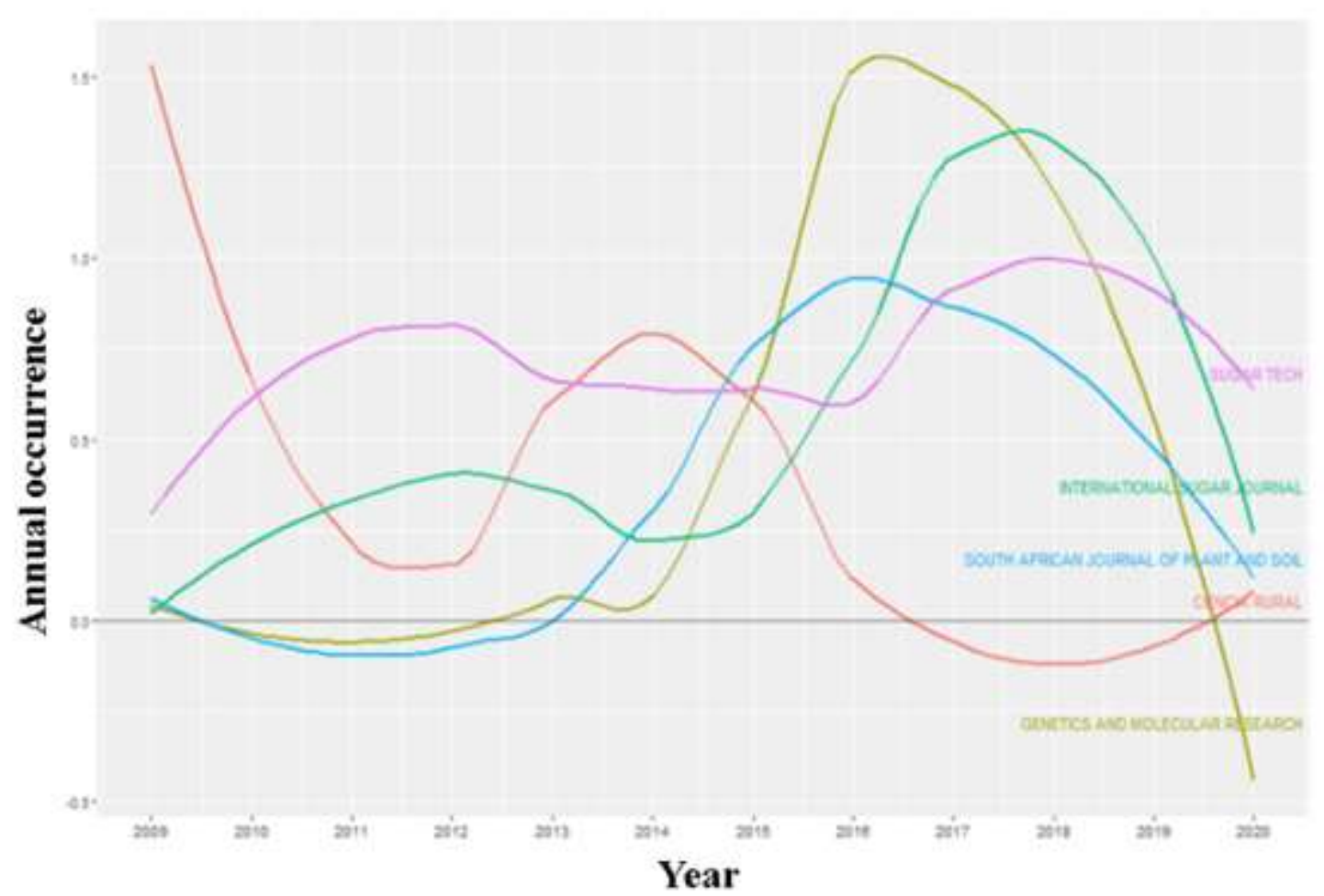

Source: Authors (2021).

According to Figure 3, the period with the highest publication peak on the genetic gain in sugarcane was 2017. The highest number of publications by Brazilian authors was between 2015 and 2017. Several multivariate selection indices were used to predict genetic gain and select superior genotypes in sugarcane breeding (L. A. Silva et al., 2017). Different selection indices were evaluated, such as Smith (1936) and Hazel (1943) and Mulamba and Mock (1978), Williams (1962), and the Pesek and Baker index (1969) (de Azeredo et al., 2017). These indexes provide information about the release of the best sugarcane clones, allowing the best genotypes with greater production predictability.

The application of selection indexes can be exemplified by Dutra Filho et al. (2014), was evaluated the agroindustrial performance of 22 sugarcane genotypes adaptable to edaphoclimatic conditions in microregions in the State of Pernambuco. The genetic gain was estimated using the classic index and the sum of the rankings. Genotype selection was efficient for tons of pol per hectare (TPH), the tonnage of cane per hectare $(\mathrm{TCH})$, and total recoverable sugar per hectare (ATR t/ha). The 
genotypes showed great potential for breeding and similar response patterns in the Coastal North and Sul microregions for TPH and TCH and in the Litoral Norte and Litoral Sul microregions for ATR t/ha. Table 1 highlights the models used in sugarcane genetic gain and their respective variables used in the indexed databases of Scopus and web of Science.

Table 1. Mathematical models and variables used to estimate genetic gain in sugarcane, reported in the literature from 2009 to 2019.

\begin{tabular}{|c|c|c|c|c|}
\hline $\mathrm{N}$ & Statistical method & Mathematical Model of Genetic Gain & Authors & Variables \\
\hline 1 & $\begin{array}{c}\text { Mixed Linear } \\
\text { Models }\end{array}$ & $Y_{i j k}=\mu+G_{i}+R_{j}+C_{k}+C G_{i k}+\epsilon_{i j k}$ & (Dumont et al., 2019) & ERS, FIB \\
\hline 2 & $\begin{array}{l}\text { Mixed Linear } \\
\text { Models }\end{array}$ & $Y=X r+Z a+W p+S f+T b+\epsilon$ & (Verissimo et al., 2018) & NSC, DP, SH, BRIX \\
\hline 3 & $\begin{array}{l}\text { Mixed Linear } \\
\text { Models }\end{array}$ & $Y_{i j k}=\mu+R_{i}+F_{j}+F R_{i j}+G(F R)_{k i j}$ & (Mbuma et al., 2017) & IGS \\
\hline 4 & Selection indexes & $Y=X f+Z g+W b+\epsilon$ & (L. A. Silva et al., 2017) & $\begin{array}{l}\text { BRIX, POL, POLS, FIB, } \\
\text { PUR }\end{array}$ \\
\hline 5 & Selection indexes & $Y=X r+Z f+W b+S c+\epsilon$ & $\begin{array}{c}\text { (de Azeredo et al., } \\
\text { 2017) }\end{array}$ & TPH, TCH, ATR, ATR/ha \\
\hline
\end{tabular}

Y - Observation of the genotype in the models. X- Potential of genotypes in models. ERS - Estimated Recoverable Sugar Cane Yield; FIB fiber content; NSC - Number of stems per ratoon cane; SH - the average height of the peduncle; DP - mean diameter of the stem; BRIX; IGS - family with individual genotype selection; POL - apparent sucrose content in the juice; POLS - apparent sucrose content in sugarcane; PUR - purity content; TPH - Tonnage of sucrose per hectare; TCH - sugarcane tonnage per hectare; ATR - total recoverable sugar tonnage; ATR / ha total tonnage of recoverable sugar per hectare.

Source: Authors (2021).

In-plant genetic breeding, predicting genetic gains through different selection strategies is one of the main contributions of quantitative genetics, as these strategies allow for guiding the program process more effectively, predicting the result of the adopted selective scheme, and decide, on a scientific basis, as to the efficiency of the breeding (Bhering et al., 2012). In this context, selection indices are essential tools because they allow the selection of superior genotypes and obtaining a numerical value that works as an additional theoretical characteristic, combining specific characteristics selected by breeders and for which simultaneous selection is desired, which is genetically superior plants are typically the ability to produce a higher yield and answer consumer demands (Crevelari et al., 2019; Cruz, 2013).

Mixed models, also known as the REML/BLUP method, are important selection tools for genetic development and allow accurate and unbiased prediction of breeding values even under unbalanced conditions. BLUP (Best Unbiased Linear Prediction) is a recommended procedure in the prediction of breeding values using estimated variance components via REML (Residual or Restricted Maximum Likelihood) (W. P. Rodrigues et al., 2013). BLUP facilitates the simultaneous use of information on the individual, family, and repeated measures over time, providing more accurate estimates of the components of genetic variation and individual genetic values (T. B. Pereira et al., 2013).

After a detailed analysis of 25 articles with mathematical models, the mixed linear model with 15 expressions was predominant in the series studied from 2009-2019, followed by selection indexes with three expressions. The author who most stands out using this methodology was Marvelous Zhou (9 articles). In addition to the expressions highlighted in Table 1, mixed linear models have other mathematical expressions. The most frequently studied variables were: ERS - Estimated recoverable sugarcane yield; FIB - fiber content; BRIX; POL - apparent sucrose content in the juice; POLS - apparent sucrose content in sugarcane; PUR - purity content; TPH - Tonnage of sucrose per hectare; TCH - sugarcane tonnage per hectare; ATR - total recoverable sugar tonnage; ATR / ha total tonnage of recoverable sugar per hectare.

In Figure 4, there is an analysis of the authors' citations from 2009 to 2019 . Zhou was the researcher with the highest 
number of citations (56), followed by Hogarth, D.M. (17) citations. This result may be associated with author Zhou's prominence in developing works using mixed linear models. The results illustrate that knowledge about genetic gain in sugarcane is in the multiplication phase and generation of interest by authors in the academic community.

Figure 4. Authors of studies on the genetic gain in sugarcane most cited in the period from 2009 to 2019.

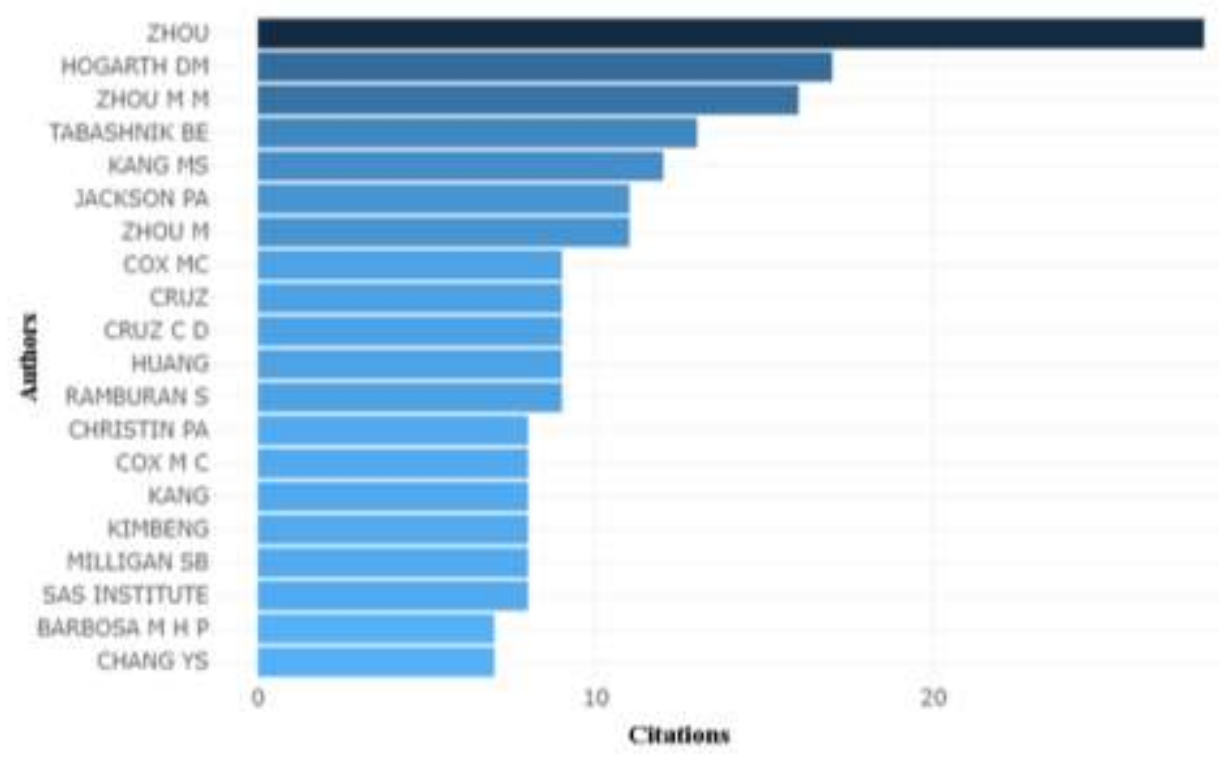

Source: Authors (2021).

Brazil occupies the first position among the countries with the most outstanding scientific production on the subject, with 111 articles, followed by the United States of America (45), Australia (35), and South Africa (30). In terms of citation, the countries of origin of the most cited manuscripts were the United States of America with 597 citations, Brazil with 457, and Australia with 106 citations (Figure 5). The highlight of Brazil regarding scientific publication and citations can be explained by the fact that it ranks as the second-largest sugarcane producer in the world, surpassed by India, which has led as the leading producer since 2017. According to perspectives pointed out in the document of the Organization for Economic Cooperation and Development (OECD) and the Food and Agriculture Organization of the United Nations (FAO), the country will return to the position of the most significant product in the subsequent harvests and should remain until the year 2039(OECD/FAO, 2020). 
Figure 5. Geographical distribution of countries by scientific production from the Scopus and web of Science indexed databases from 2009 to 2019.

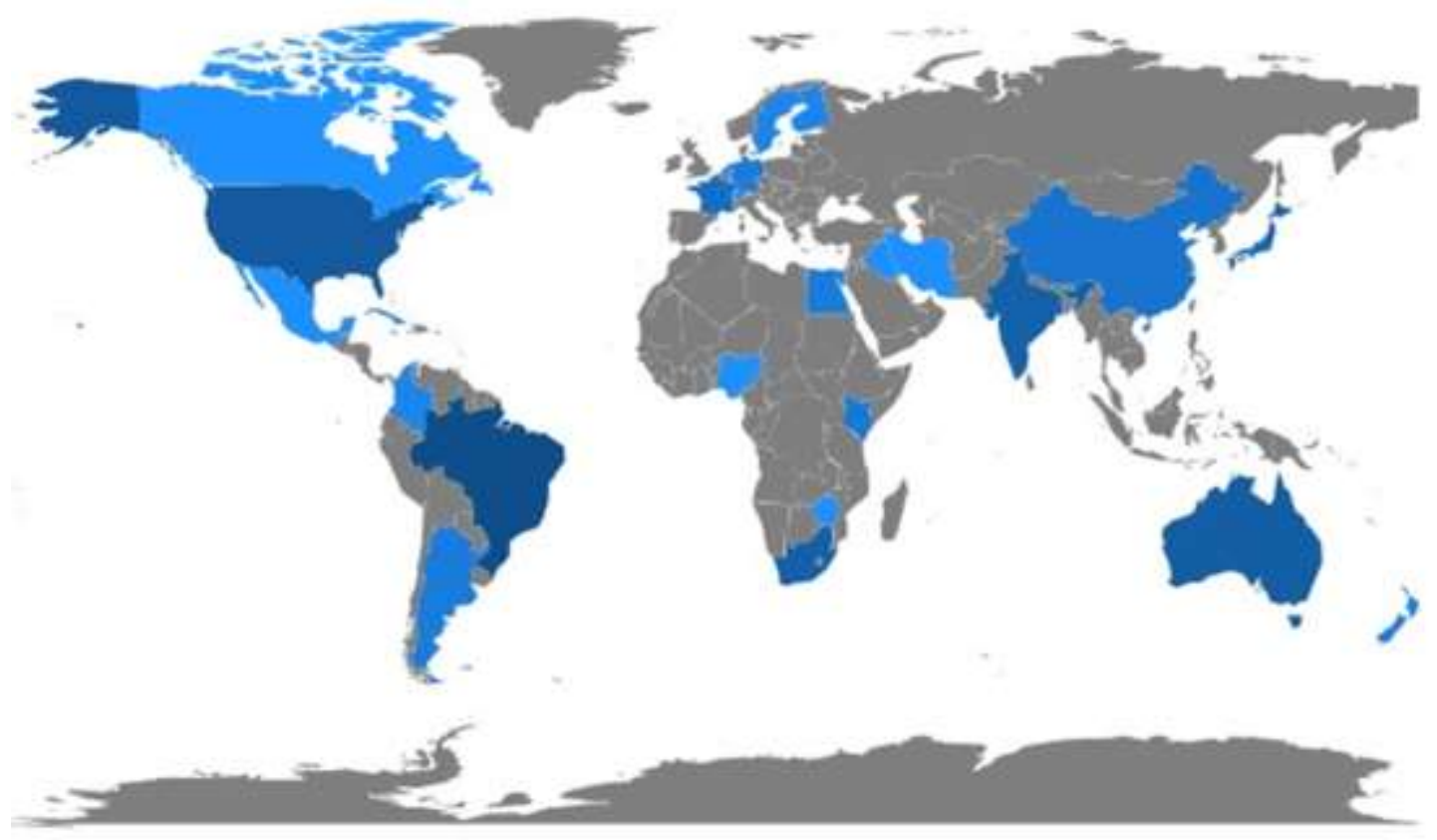

Source: Authors (2021).

In Figure 6, the countries with a research center on genetic improvement and are part of the UPOV. Among the 25 articles, South Africa, Brazil, Argentina, and China are members of the UPOV and adhere to the 1978 minutes. France, the United States of America, and Australia are members of the 1991 UPOV. Breeding programs have developed adapted varieties to environments with specific soil conditions, climate, harvest season, greater tolerance to water stress, greater resistance to pests and diseases, and better adaptation to the harvest. Highly productive varieties adapted to different environments and with added value have been the basis for expanding genetic improvement in several countries. Thus, the seed production process involves research, development, and innovation ( $R \& R \& R \& D \& I)$, the licensing of technologies, and the coordination of interests in the seed chain to guarantee the collection of royalties on the technologies present in the commercialized varieties (Teles \& Fuck, 2019). 
Figure 6. According to the systematic review, the geographical distribution of countries with sugarcane breeding centers is part of the International Union for the Protection of New Varieties of Plants (UPOV).

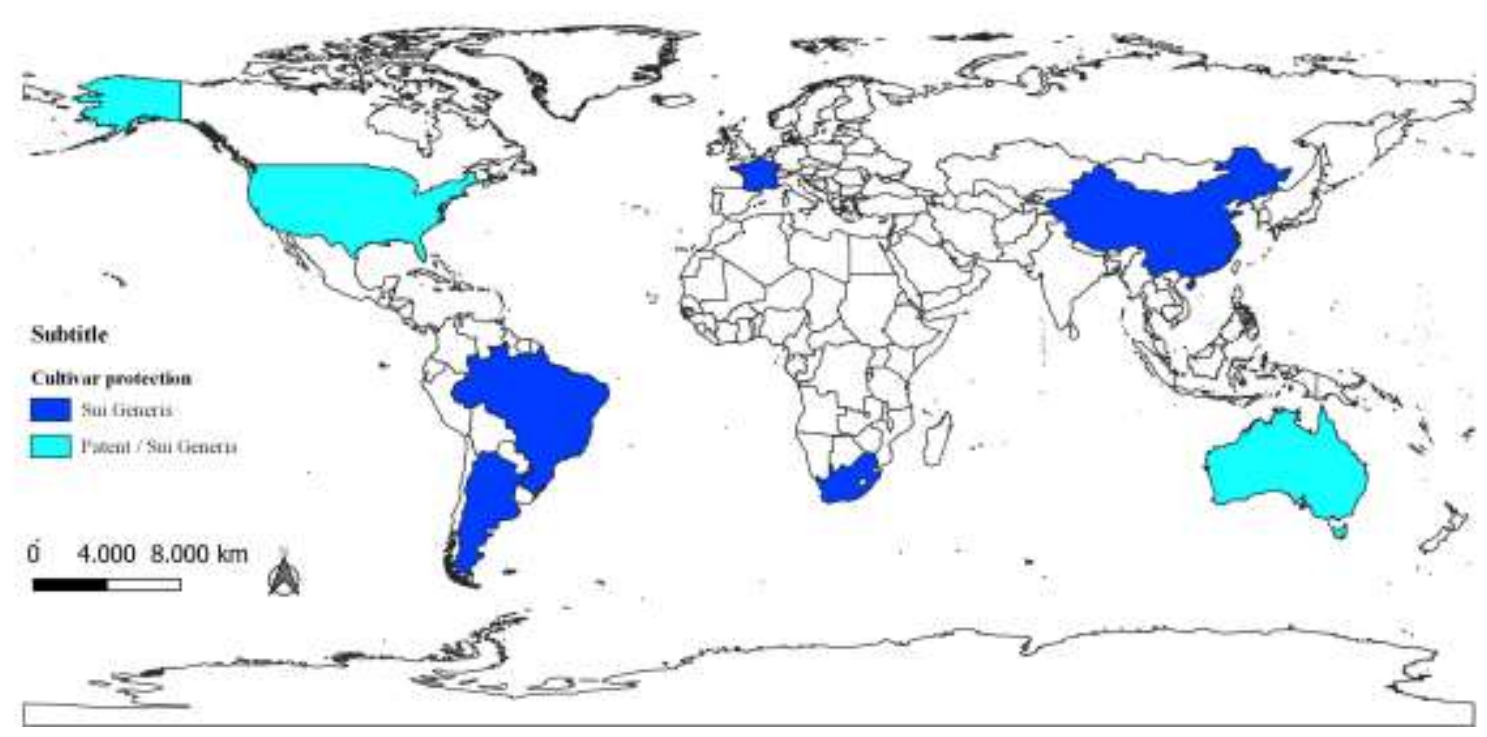

Source: Authors (2021).

Some countries have adopted a patent/sui generis system among the forms of protection, as the United States and Australia. Others have adopted the sui generis system of new cultivars, like Brazil, Argentina, France, South Africa, and China. Patent protection requires the integration of several complementary technologies in the development of genetically modified cultivars encompassing three types of technologies: 1) genetic sequences; 2) enabled technologies; and 3) germplasm. In this way, the technology holder can charge royalties from third parties to use these cultivars. The sui generis protection assures the breeder the property rights over the developed cultivar and the royalties arising from its commercialization. The United States, in 1930, enacted a law known as the Plant Patent Act, which established patent rights for breeders of new plant varieties. IP protection of plant varieties was supplemented in the US by enacting the Plant Variety Protection Act of 1970 (PVPA), which introduced UPOV type protection (Correa et al., 2015).

Europe does not allow the granting of a patent for a plant variety. The only way to protect a plant variety is by Plant Breeders' Rights (PBR), as defined by the UPOV Convention. The granting of PBR is regulated by the European Community (EC). The rights of plant breeders are subject to the legislation of each country (Le Buanec \& Ricroch, 2014). After ratifying accession to the WTO, Brazil became obligated to change the old legislation that did not protect new cultivars (variety and hybrids). The country inserted into the national legal system Law No. 9,456, known as the Cultivar Protection Law (LPC). Since then, there has been a change in the panorama of cultivar development in the country. Other legal norms acted as apparatus for the development of protected cultivars, such as the Seeds and Seedlings Law, ${ }^{\circ}$ 10.711, of August 5, 2003, and its regulatory decree $\mathrm{n}^{\circ} 5.153$, of July 23, 2004, and the Law of Technological Innovation, $\mathrm{n}^{\circ}$ 10.973, of December 2, 2004. The first two minimized distortions in applying LPC regarding the production and commercialization of seeds and seedlings of protected cultivars. The Law of Incentives for Innovation and Scientific and Technological Research, in turn, created a favorable environment for scientific research, including plant improvement.

In Brazil, the law of incentives to innovation and scientific and technological research in the productive environment, in its Article 13, the obtainer of innovation is guaranteed a minimum share in the economic gains earned by the Scientific, Technological and Innovation Institution (ICT), resulting from technology transfer and licensing agreements for granting the right to use or exploit protected creations. In paragraph 2 of article 13, economic gain is understood to be any form of royalty 
or remuneration or any financial benefits resulting from the direct exploitation or by third parties of the protected creation (BRASIL, 2004). Under Article 14 of the 1991 UPOV, breeders' rights now include producing and reproducing seeds, material from the harvest, and new varieties essentially derived from others. In the latter case, the variety improved from another by a minimum number of characteristics defined by law, as long as the essential characteristics of the initial variety are maintained, requires the holder's permission of the rights and payment of royalties. In Figure 7, according to the systematic review in general, the internal collaboration index (SCP) is more frequent concerning the external collaboration index (MCP).

Figure 7. Relationship of scientific collaboration between countries according to the internal collaboration index (SCP) and the collaboration index between countries (MCP) from the Scopus and web of Science indexed databases from 2009 to 2019.

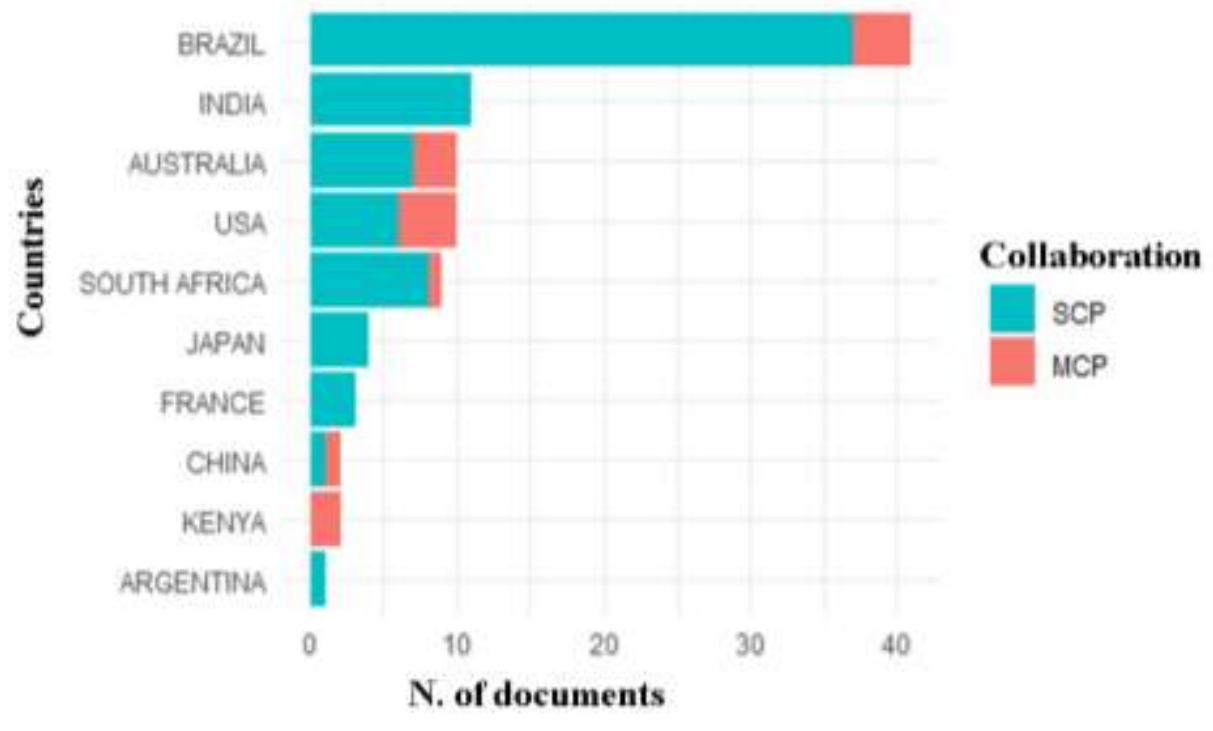

Source: Authors (2021).

Brazil stands out the most concerning scientific collaboration regarding genetic gain in sugarcane, with an internal collaboration index (SCP) of $90.24 \% \%$ concerning an external collaboration index (MCP) of $9.7 \%$. Thus, the forms of collaboration are more closely related due to a research and improvement network that brings together researchers from the public and private sectors. This internal collaboration shows that breeding programs seek to develop genetically superior cultivars that combine the maximum number of desirable characters to contribute positively to the sugarcane industry. In addition to genetic improvement, the economic gain in sugarcane production can be achieved in other ways, including through the expansion of the cultivation area, improvement in the management system, production, and harvesting, innovation and production scientific (De Morais et al., 2015).

South Africa has an internal collaboration index (SCP) of 88.88\% compared to an external collaboration index (MCP) of $11 / 11 \%$, forms of collaboration are more strongly related to local researchers. The researchers have as one of their goals the genotype versus environment $(\mathrm{G} \times \mathrm{E})$ interaction in the influence of values on genetic gains of sugarcane when breeding materials are evaluated in different agroecological areas. Agroecological environments can vary from one region to another within regions. In situations where $\mathrm{G} \times \mathrm{E}$ is large, relatively significant genetic gains can be achieved by selecting specific genotypes for each distinct environment (Zhou \& Gwata, 2015).

The relationship of universities in cooperation and the internal collaboration of knowledge promotes changes in protecting technologies, particularly the genetic improvement of plants. Innovation and public investments are crucial to creating new markets for plant improvement. The development of a new cultivar results from years of investment in research 
on plant genetic improvement and involves researchers and partnerships between public and private institutions. In this way, this internal research collaboration between researchers in the countries of origin can contribute to collecting royalties on protected genetic material. In Figure 8, according to the systematic review among universities that research on the genetic gain in sugarcane, the one that stood out was the Federal University of Viçosa (UFV) with 18 articles published in the period from 2009 to 2019, followed by South African Sugarcane Research Institute (SASRI) with 12 articles published in 10 years.

RIDESA's research activities are developed and shared among universities, encouraging the exchange of information, knowledge, and results. UFV is one of three (3) institutions that appear among the 20 in the ranking with the highest number of publications. Thus, the highlight of these universities in many publications reflects the results of research and innovation in the sector.

Figure 8. List of universities with scientific production on the genetic gain in sugarcane from the Scopus and web of Science databases indexed from 2009 to 2019.

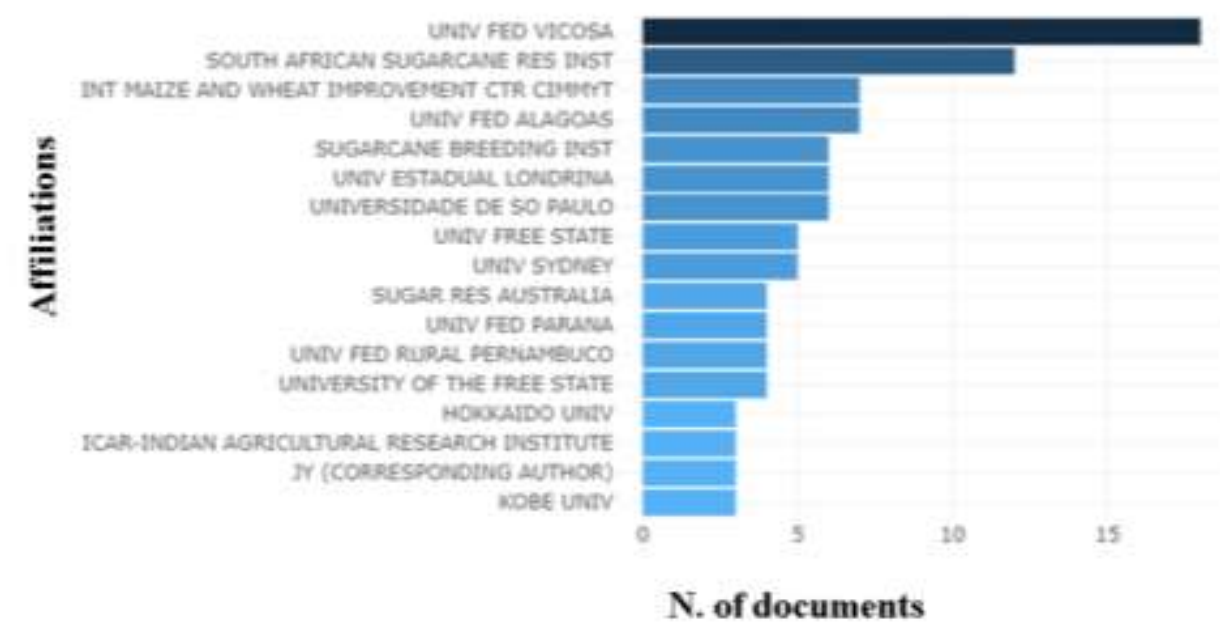

Source: Authors (2021).

Universities are essential to process planning and control, as they enable the establishment of quantitative and qualitative goals in genetic breeding, both for decision-making and re-planning. Knowledge in universities and research centers in genetic has gained prominence, considering that the result of academic research is successfully transferred (commercial application) to society, all actors involved end up benefiting from this generation of value. Through this process, laws were disseminated, granting universities the right to intellectual property (IP), the commercialization of technologies, and incentives to finance research in the development of new cultivar (Bueno \& Torkomian, 2018).

Scientific research, which takes place in the university breeder's laboratory, followed by the invention that transforms the innovation capable of protection, generates the rights of universities regarding the asset generated, the genetic improvement of plants. Soon after, there is the valuation of this technology, which aims to commercialize intellectual property (IP). Therefore, the breeder's rights in universities must be paid through royalties, which have been used to represent the remuneration obtained for the commercial exploitation of IP rights in the launch of new plant cultivars.

In addition to conventional breeding, professors and researchers from the different federal universities that make up RIDESA have also been working with sugarcane biotechnology, with the primary objective of supporting genetic improvement activities and training human resources to work in this crucial area. As is the case throughout Brazil, as in the 
center-south where other research centers charge royalties per hectare for the new sugarcane cultivar created and used by most producers in that region, RIDESA, the network responsible for the genetic breeding and intellectual property of most of the sugarcane cultivars used in the Northeast, also charges royalties from local sugarcane producers, based on the Federal Law of Cultivars (9,456/1997) (RIDESA, 2021).

Specifically, through the use of biotechnology, some innovations were obtained with sugarcane, they are genetically modified cultivars such as CTC20Bt and CTC9001BT resistant to the sugarcane borer (Diatraea saccharalis), which were approved for cultivation and use of food/ rations in Brazil by the National Technical Commission on Biosafety (CNTBio) Also, through biotechnology, researchers from Brazil, the United States, and France studied a transcription factor RAV, from the ethylene response factor superfamily; and an endo-poly-galacturonase (EPG) related to the hydrolysis of homogalacturonan of the middle lamella, their results contributed to elucidate cell wall degradation in sugarcane and may figure as the first step to acquire control of cell wall hydrolysis in sugarcane. de-sugar through biotechnology, facilitating the production of bioethanol (Tavares et al., 2019).

\section{Conclusion}

Estimation of genetic gain is fundamental in charging royalties on improved genetic material. This charge must be carried out taking into account the technology used over several years. Thus, the breeder must be compensated by intellectual property rights for research and technological innovation attributed to the genetic improvement of new plants.

Brazil stands out among the countries with the most remarkable scientific production. In which forms of collaboration are more strongly related to local researchers. The index of internal collaboration in developing a new cultivar and involving researchers and partnerships between public and private institutions among researchers in the countries of origin can contribute to the collection of royalties on the protected genetic material.

The models proposed in the estimation of genetic gain in sugarcane for breeding estimation may be possible to develop a royalty valuation model introducing a new definition of genetic gain based on the yield year increase and the continuous release of new cultivars over time. Therefore, the end of the vicious cycle of royalty collection that only considers the costs of producing new genetically improved plant varieties is expected to end.

We emphasize the need for future work to investigate specific cases of genetic gain linked to the payment of royalties. Since the articles found, explicit how new cultivars are released considers only the production costs. Recognition of the breeder for the genetic material developed must consider the costs of the operation and the technology used in the development of new plant varieties. Thus, it is expected that recognition of intellectual property to the breeder through royalties will be converted into research and innovation, and genetic improvement centers will be guaranteed.

\section{Acknowledgments}

This work was carried out with the support of the Coordination for the Improvement of Higher Education Personnel Brazil (CAPES) - Financing Code 001.

\section{References}

Aria, M., \& Cuccurullo, C. (2017). bibliometrix: An R-tool for comprehensive science mapping analysis. Journal of Informetrics, 11(4), 959-975. https://doi.org/10.1016/j.joi.2017.08.007

Bezerra, J. D. C., Ferreira, G. D. G., Oliveira, M. W. de, Campos, J. M. de S., Andrade, A. P. de, \& Nascimento Júnior, J. R. S. do. (2018). Sugar cane: genetic improvement and forage purposes. Nucleus Animalium, 10(2), 131-147. https://doi.org/10.3738/21751463.3518

Bhering, L. L., Laviola, B. G., Salgado, C. C., Sanchez, C. F. B., Rosado, T. B., \& Alves, A. A. (2012). Genetic gains in physic nut using selection indexes. Pesquisa Agropecuaria Brasileira, 47(3), 402-408. https://doi.org/10.1590/S0100-204X2012000300012 
BRASIL. (1997). Lei $n^{o}$ 9.456, de 25 de abril de 1997. Institui a Lei de Proteção de Cultivares e Dá Outras Providências. http://www.planalto.gov.br/ccivil_03/leis/19456.htm

BRASIL. (2003). Lei $n^{o}$ 10.711, de 5 de agosto de 2003. Dispõe Sobre o Sistema Nacional de Sementes e Mudas e Dá Outras Providências. http://www.planalto.gov.br/ccivil_03/leis/2003/110.711.htm

BRASIL. (2004). Lei $n^{\circ}$ 10.973, de 2 de dezembro de 2004. Dispõe Sobre Incentivos à Inovação e à Pesquisa Científica e Tecnológica No Ambiente Produtivo e Dá Outras Providências. http://www.planalto.gov.br/ccivil_03/_ato2004-2006/2004/lei/110.973.htm

BRASIL. (2017). Extrato de parecer técnico $n^{o}$ 5.483/2017. Comissão Técnica Nacional de Biossegurança - CTNBio. Diário Oficial Da República Federativa Do Brasil. https://www.in.gov.br/materia/-/asset_publisher/Kujrw0TZC2Mb/content/id/55445015

BRASIL. (2018). Extrato de parecer técnico $n^{\circ}$ 6.235/2018. Comissão Técnica Nacional de Biossegurança - CTNBio. Diário Oficial Da República Federativa Do Brasil. https://www.in.gov.br/materia/-/asset_publisher/Kujrw0TZC2Mb/content/id/55445015

Bruch, K. L., \& Pinto Vieira, A. C. (2016). Inovação e desenvolvimento tecnológico na rizicultura: uma análise da proteção de cultivares. Revista de Propriedade Intelectual - Direito Constitucional e Contemporâneo, 10(1), 234-260. https://doi.org/10.16928/2316-8080.V10N1p.234-260

Bueno, A., \& Torkomian, A. L. V. (2018). Índices de licenciamento e de comercialização de tecnologias para núcleos de inovação tecnológica baseados em boas práticas internacionais. Encontros Bibli: Revista Eletrônica de Biblioteconomia e Ciência Da Informação, 23(51), 95-107. https://doi.org/10.5007/15182924.2018v23n51p95

Correa, C. M., Shachikant, S., \& Meienberg, F. (2015). Plant Variety Protection for Developing Countries. A Tool to Design a Sui Generis Plant Variety Protection System: An Alternative to UPOV 1991. APBREBES. https://www.apbrebes.org/news/plant-variety-protection-developing-countries-tool-design-suigeneris-plant-variety-protection

Crevelari, J. A., Pereira, M. G., Azevedo, F. H. V., \& Vieira, R. A. M. (2019). Genetic improvement of silage maize: predicting genetic gain using selection indexes and best linear unbiased prediction. Revista Ciência Agronômica, 50(2), 197-204. https://doi.org/10.5935/1806-6690.20190023

Cruz, C. D. (2013). GENES - Software para análise de dados em estatística experimental e em genética quantitativa. Acta Scientiarum - Agronomy, 35(3), 271-276. https://doi.org/10.4025/actasciagron.v35i3.21251

de Azeredo, A. A. C., Bhering, L. L., Brasileiro, B. P., Cruz, C. D., Silveira, L. C. I., Oliveira, R. A., Bespalhok Filho, J. C., \& Daros, E. (2017). Comparison between different selection indices in energy cane breeding. Genetics and Molecular Research, 16(1), 1-12. https://doi.org/10.4238/gmr16019535

De Morais, L. K., De Aguiar, M. S., De Albuquerque E Silva, P., Marinho Câmara, T. M., Cursi, D. E., Fernandes Jú Nior, A. R., Chapola, R. G., Carneiro, M. S., \& Bespalhok Filho, J. C. (2015). Breeding of sugarcane. In Industrial Crops: Breeding for Bioenergy and Bioproducts (pp. 29-42). Springer New York. https://doi.org/10.1007/978-1-4939-1447-0_2

Donato, H., \& Donato, M. (2019). Etapas na Condução de uma Revisão Sistemática. Acta Médica Portuguesa, 32(3), 227. https://doi.org/10.20344/amp.11923

Dumont, T., Thong-Chane, A., Barau, L., Siegmund, B., \& Hoarau, J.-Y. (2019). Genetic Variabilities and Genetic Gains for Yield Components in Regional Sugarcane Breeding Programmes on Réunion Island. Sugar Tech, 21(6), 868-878. https://doi.org/10.1007/s12355-019-00718-9

Dutra Filho, J. A., Junior, T. C., \& Simões Neto, D. E. (2014). Phenotype adaptability and stability of sugarcane genotypes in the sugarcane belt of the State of Pernambuco, Brazil. Genetics and Molecular Research, 13(3), 6865-6877.

EMBRAPA. (2021). Árvore do conhecimento cana-de-açúcar. https://www.agencia.cnptia.embrapa.br/gestor/cana-de-acucar/arvore/CONTAG01_33_ 711200516717.html.

Endres, A. B., \& Goldsmith, P. D. (2007). Alternative business strategies in weak intellectual property environments: A law \& economics analysis of the agrobiotechnology firm's strategic dilemma. Journal of Intellectual Property Law, 14(2)(237-268).

Goldsmith, P., Ramos, G., \& Steiger, C. (2006). Intellectual property piracy in a North-South context: empirical evidence. Agricultural Economics, 35(3), 335-349. https://doi.org/10.1111/j.1574-0862.2006.00166.x

Hervouet, A., \& Langinier, C. (2018). Plant breeders' rights, patents, and incentives to innovate. Journal of Agricultural and Resource Economics, 43(1), 118150. https://doi.org/10.22004/ag.econ.267613

Juk, Y. V., \& Fuck, M. P. (2020). Questões sobre proteção de cultivares no Brasil. Cadernos de Ciência \& Tecnologia, 37(3), 26794. https://doi.org/10.35977/0104-1096.cct2020.v37.26794

Le Buanec, B., \& Ricroch, A. (2014). Intellectual property protection of plant innovation. In Plant Biotechnology: Experience and Future Prospects (Vol. 9783319068923, pp. 59-73). Springer International Publishing. https://doi.org/10.1007/978-3-319-06892-3_6

Masuka, B., Atlin, G. N., Olsen, M., Magorokosho, C., Labuschagne, M., Crossa, J., Bänziger, M., Pixley, K. V., Vivek, B. S., von Biljon, A., Macrobert, J., Alvarado, G., Prasanna, B. M., Makumbi, D., Tarekegne, A., Das, B., Zaman-Allah, M., \& Cairns, J. E. (2017). Gains in Maize Genetic Improvement in Eastern and Southern Africa: I. CIMMYT Hybrid Breeding Pipeline. Crop Science, 57(1), 168-179. https://doi.org/10.2135/cropsci2016.05.0343

Mbuma, N. W., Zhou, M. M., \& van der Merwe, R. (2017). Identifying Elite Families and Determining Optimum Family Selection Rates in Sugarcane Breeding. Crop Science, 57(5), 2525-2537. https://doi.org/10.2135/cropsci2017.01.0011

Medeiros, I. L., Vieira, A., Braviano, G., \& Gonçalves, B. S. (2015). Systematic Review and Bibliometrics facilitated by a Canvas for information visualization. InfoDesign - Brazilian Journal of Information Design, 12(1), 93-110. https://www.infodesign.org.br/infodesign/article/view/341 
MINISTÉRIO DE MINAS E ENERGIA. (2021). RonovaBio. http://antigo.mme.gov.br/web/guest/secretarias/petroleo-gas-natural-e-biocombustiveis/acoes-eprogramas/programas/renovabio.

Morini, M. S. de C., Silva, O. G. M. da, Zambon, V., \& Nocelli, R. C. F. (2017). Cultura de Cana-de-açúcar no Brasil: Manejo, Impactos Econômicos, Sociais e Ambientais. In Cana-de-açúcar e seus impactos: uma visão acadêmica. Organizadores: Fontanetti, S. e Bueno, O. C. (pp. 31-50). Canal 6.

OECD/FAO. (2020). Sugar. In OECD-FAO Agricultural Outlook 2020-2029 (pp. 150-161). Rome/OECD.

Page, M. J., McKenzie, J. E., Bossuyt, P. M., Boutron, I., Hoffmann, T. C., Mulrow, C. D., Shamseer, L., Tetzlaff, J. M., Ak1, E. A., Brennan, S. E., Chou, R., Glanville, J., Grimshaw, J. M., Hróbjartsson, A., Lalu, M. M., Li, T., Loder, E. W., Mayo-Wilson, E., McDonald, S., \& Moher, D. (2021). The PRISMA 2020 statement: an updated guideline for reporting systematic reviews. BMJ, 71. https://doi.org/10.1136/bmj.n71

Pereira, R. S., Santos, I. C., Oliveira, K. D. S., \& Leão, N. C. A. (2019). Meta-analysis as a research tool: a systematic review of bibliometric studies in administration. RAM. Revista de Administração Mackenzie, 20(5). https://doi.org/10.1590/1678-6971/eramg190186

Pereira, T. B., Carvalho, J. P. F., Botelho, C. E., Resende, M. D. V. de, Rezende, J. C. de, \& Mendes, A. N. G. (2013). Eficiência da seleção de progênies de café F4 pela metodologia de modelos mistos (REML/BLUP). Bragantia, 72(3), 230-236. https://doi.org/10.1590/brag.2013.031

QGIS.org. (2021). QGIS Geographic Information System (3.4). QGIS Association. . https://docs.qgis.org/3.16/en/docs/developers_guide/index.html

R Core Team. (2020). R: A language and environment for statistical computing (4.0.2). R Foundation on Statistical Computing (1.3.1073).

RIDESA. (2021). Melhoramento Genético da Cana-de-açúcar. https://www.ridesa.com.br/

Rodrigues, R. S., \& Fachin, G. R. B. (2010). Portal de periódicos científicos: um trabalho multidisciplinar. Transinformação, $22(1)$, 33-45. https://doi.org/10.1590/S0103-37862010000100003

Rodrigues, W. P., Vieira, H. D., Barbosa, D. H. S. G., Souza Filho, G. R., \& Candido, L. S. (2013). Adaptability and genotypic stability of Coffea arabica genotypes based on REML/BLUP analysis in Rio de Janeiro State, Brazil. Genetics and Molecular Research, 12(3), 2391-2399.

RStudio Team. (2016). RStudio: Integrated Development for R (1.1.463). MA: RStudio. http://www.rstudio.com/

Sá, C. D. de. (2018). Estratégias de apropriação de valor: conectando a visão baseada em recursos à teoria de direitos de propriedade. Universidade de São Paulo.

Sembay, M., Luiz Pinto, A., De Macedo, D. D. J., \& Moreiro-González, J. A. (2020). Aplicação da Lei de Bradford a pesquisas relacionadas a Open Government. Anales de Documentación, 23(1), 1-10. https://doi.org/10.6018/analesdoc.326771

Silva, E. J. de S., Silva-Mann, R., \& Calazans, C. C. (2021). Royalties para cultivares, legislação e regulação: Uma meta-análise. Research, Society and Development, 10(4), e31710414231. https://doi.org/10.33448/rsd-v10i4.14231

Silva, L. A., Teodoro, P. E., Peixoto, L. A., Assis, C., Gasparini, K., Barbosa, M. H. P., \& Bhering, L. L. (2017). Selecting sugarcane genotypes by the selection index reveals high gain for technological quality traits. Genetics and Molecular Research, 16(2), 1-12. https://doi.org/10.4238/gmr16029678

Tavares, E. Q. P., De Souza, A. P., Romim, G. H., Grandis, A., Plasencia, A., Gaiarsa, J. W., Grima-Pettenati, J., de Setta, N., Van Sluys, M.-A., \& Buckeridge, M. S. (2019). The control of endopolygalacturonase expression by the sugarcane RAV transcription factor during aerenchyma formation. Journal of Experimental Botany, 70(2), 497-506. https://doi.org/10.1093/jxb/ery362

Teles, G. C., \& Fuck, M. P. (2019). Inovação e apropriabilidade sobre sementes de soja no Brasil. Revista de Economia, 39(69), 1-29. https://doi.org/10.5380/re.v39i69.67892

Verissimo, M. A. A., Oliveira, R. A. de, Silva, S. D. dos A. e, Daros, E., \& Härter, A. (2018). Genetic parameters and performance of sugarcane families under cold stress in the South of Brazil. Pesquisa Agropecuária Brasileira, 53(5), 583-592. https://doi.org/10.1590/s0100-204x2018000500007

Zhou, M. M., \& Gwata, E. T. (2015). Location Effects and Their Implications in Breeding for Sugarcane Yield and Quality in the Midlands Region in South Africa. Crop Science, 55(6), 2628-2638. https://doi.org/10.2135/cropsci2015.02.0101

Zhou, M. M., \& Gwata, E. T. (2016). Quantifying Sugarcane Cultivar Genetic Gains in the Midlands Region of South Africa. Agronomy Journal, 108(1), 342348. https://doi.org/10.2134/agronj2015.0141 